\begin{tabular}{|l|l|l||}
\hline \multicolumn{2}{|c|}{ PublisherInfo } \\
\hline \hline PublisherName & $:$ & BioMed Central \\
\hline \hline PublisherLocation & $:$ & London \\
\hline \hline PublisherImprintName & $:$ & BioMed Central \\
\hline \hline
\end{tabular}

\title{
Targeting human transgenes
}

\begin{tabular}{|l|l|l||}
\hline \multicolumn{2}{|c|}{ ArticleInfo } \\
\hline \hline ArticleID & $:$ & 4519 \\
\hline \hline ArticleDOI & $:$ & $10.1186 /$ gb-spotlight-20020702-01 \\
\hline \hline ArticleCitationID & $:$ & spotlight-20020702-01 \\
\hline \hline ArticleSequenceNumber & $:$ & 185 \\
\hline \hline ArticleCategory & $:$ & Research news \\
\hline ArticleFirstPage & $:$ & 1 \\
\hline \hline ArticleLastPage & $:$ & 2 \\
\hline \hline & & RegistrationDate : 2002-7-2 \\
\hline ArticleHistory & $:$ & OnlineDate \\
\hline \hline ArticleCopyright & $:$ & BioMed Central Ltd2002-7-2 \\
\hline \hline ArticleGrants & $:$ & \\
\hline \hline ArticleContext & $:$ & 130593311 \\
\hline \hline
\end{tabular}




\section{Jonathan B Weitzman}

Email: jonathanweitzman@hotmail.com

Adeno-associated viruses (AAVs) are single-stranded DNA vectors that have shown promise as genetargeting vectors for experimental and therapeutic applications. In the July issue of Nature Biotechnology, Roli Hirata and colleagues at the University of Washington, Seattle, describe a way of using AAV to introduce a functional transgene cassette into defined genomic loci in human cells in culture (Nature Biotechnology 2002, 20:735-738). The AAV vectors can deliver gene cassettes of up to $1.5 \mathrm{~kb}$. Hirata et al. designed an AAV vector containing a selectable neomycin cassette within the hypoxanthine phosphoribosyl transferase (HPRT) gene. They then infected diploid male human fibroblasts, or HT1080 fibrosarcoma cells, and selected for neomycin resistance and functional HPRT expression. The targeting efficiency was as high as $1 \%$ of the total cell population. Hirata et al. also used a similar strategy to disrupt the autosomal type I collagen (COL1A1) gene in human fibroblasts. The high efficiency and accuracy of this procedure provides an effective tool for experimental and therapeutic gene targeting of specific human loci.

\section{References}

1. Human gene targeting by viral vectors.

2. Nature Biotechnology, [http://www.nature.com/nbt/]

3. University of Washington, [http://www.washington.edu]

This PDF file was created after publication. 